\title{
PEMODELAN FAKTOR RISIKO KEJADIAN HIPERTENSI DAN JANTUNG KORONER DI KOTA PADANG MENGGUNAKAN REGRESI LOGISTIK BIRESPON
}

\author{
NADYA PUTRI ALISYA, HAZMIRA YOZZA* FERRA YANUAR \\ Program Studi S1 Matematika, \\ Fakultas Matematika dan Ilmu Pengetahuan Alam, Universitas Andalas, \\ Kampus UNAND Limau Manis Padang, Indonesia. \\ email : nadyalisya3011@gmail.com,hyozza@sci.unand.ac.id,ferrayanuar@sci.unand.ac.id
}

Diterima 12 Juni $2021 \quad$ Direvisi 22 Juni $2021 \quad$ Dipublikasikan 26 Juli 2021

\begin{abstract}
Abstrak. Hipertensi dan jantung koroner merupakan penyakit dengan angka kematian tertinggi di Indonesia. Kedua penyakit ini memiliki hubungan yang erat dan diduga disebabkan oleh faktor-faktor yang sama. Pada penelitian ini akan dianalisa faktor-faktor yang mempengaruhi kejadian hipertensi dan jantung koroner secara bersama di Kota Padang. Analisis dilakukan dengan analisis regresi logistik birespon. Data yang digunakan adalah data Riskesdas Provinsi Sumatera Barat tahun 2013. Penelitian ini menggunakan 7 variabel prediktor, yaitu usia, jenis kelamin, indeks massa tubuh (IMT), kebiasaan merokok, aktifitas fisik, konsumsi buah, dan konsumsi sayur. Analisis regresi logistik birespon dilakukan dengan pengujian signifikansi parameter secara parsial dan serentak. Hasil dari pengujian signifikansi parameter menunjukkan bahwa dari ketujuh variabel prediktor, hanya variabel usia yang berpengaruh secara signifikan terhadap kejadian hipertensi dan jantung koroner di Kota Padang.
\end{abstract}

Kata Kunci: Hipertensi, Jantung koroner, Regresi logistik birespon

\section{Pendahuluan}

Hipertensi dan jantung koroner merupakan penyakit yang berhubungan erat dan biasanya terjadi secara bersamaan atau biasa disebut komorbid. Dengan adanya kondisi ini maka dapat diduga bahwa faktor yang menyebabkan terjadinya hipertensi juga sekaligus menjadi penyebab jantung koroner. Berdasarkan data Kementrian Kesehatan tahun 2018, angka kematian akibat komplikasi hipertensi yang terkait masalah jantung bahkan dilaporkan lebih tinggi dibandingkan jenis komplikasi yang menargetkan organ tubuh lain. Penelitian sebelumnya dilakukan oleh Palilati [5] yang menyimpulkan bahwa faktor risiko jantung koroner adalah hiperkolesterol, merokok, obesitas, kurang olahraga, riwayat keluarga, stres, umur, dan jenis kelamin. Penelitian lain dilakukan oleh Rahajeng [6], menghasilkan kesimpulan bahwa

${ }^{*}$ Penulis Korespondensi 
faktor risiko hipertensi adalah umur, pria, pendidikan rendah, kebiasaan merokok, konsumsi kafein yang berlebihan, konsumsi alkohol, kurang aktivitas fisik dan obesitas.

Pada penelitian ini akan dianalisa faktor risiko kejadian hipertensi dan jantung koroner secara bersama di kota Padang. Salah satu analisis statistika yang digunakan untuk melihat hubungan variabel respon dengan variabel-variabel prediktor adalah analisis regresi. Pada penelitian kali ini, terdapat dua variabel respon biner yaitu kejadian hipertensi dan jantung koroner, sehingga pendekatan model yang digunakan dalam penelitian ini adalah analisis regresi logistik birespon. Analisis regresi logistik birespon merupakan pengembangan dari analisis regresi logistik, dimana terdapat dua variabel respon biner dengan asumsi ada hubungan yang signifikan antar kedua variabel respon tersebut.

\section{Landasan Teori}

\subsection{Analisis Regresi Logistik}

Model regresi logistik yang variabel responnya terdiri dari dua kemungkinan nilai disebut dengan regresi logistik dikotomi atau biner. Kedua nilai tersebut mewakili muncul atau tidaknya suatu kejadian yang biasa diberi nilai 0 dan 1 . Seringkali juga, kedua nilai tersebut menyatakan kejadian sukses dan gagal, dengan $P($ sukses $)=$ $P(Y=1)=\pi$ dan $P($ gagal $)=P(Y=0)=1-\pi$. Untuk setiap pengamatan, variabel $Y$ yang demikian dikatakan mengikuti distribusi Bernoulli [4].

Bentuk persamaan regresi logistik biner dengan $k$ variabel prediktor adalah sebagai berikut :[3]

$$
\pi(\boldsymbol{x})=\frac{\exp \left(\beta_{0}+\beta_{1} x_{1}+\cdots+\beta_{k} x_{k}\right)}{1+\exp \left(\beta_{0}+\beta_{1} x_{1}+\cdots+\beta_{k} x_{k}\right)}
$$

dimana $\boldsymbol{x}=\left(x_{1}, x_{2}, \cdots, x_{k}\right)$ adalah vektor variabel prediktor dan $k$ adalah banyaknya variabel prediktor.

Interpretasi koefisien parameter dapat dilakukan dengan menggunakan nilai odds ratio yang bertujuan untuk mengetahui pengaruh antara variabel prediktor terhadap variabel respon. Misalkan terdapat model regresi logistik berikut

$$
\frac{\pi_{i}}{1-\pi_{i}}=\exp \left(\beta_{0}+\beta_{1} X_{1 i}+\beta_{2} X_{2 i}+\cdots+\beta_{k} X_{k i}\right)
$$

Ruas kiri dari persamaan di atas merupakan perbandingan antara peluang berhasil $\pi_{i}$ dengan peluang gagal $1-\pi_{i}$ yang disebut odds. Perbandingan nilai odds antara dua individu biasanya diistilahkan dengan odds ratio.

\subsection{Model Regresi Logistik Birespon}

Model regresi logistik birespon adalah pengembangan dari model regresi logistik jika terdapat dua variabel respon biner, dengan asumsi ada hubungan yang signifikan antar variabel respon. Misalkan terdapat dua variabel respon $\left(Y_{1}, Y_{2}\right)$ dimana $Y_{1}$ dan $Y_{2}$ bernilai 0 atau 1 . Jika kedua variabel respon berkorelasi maka akan terdapat empat buah pasangan respon biner yang selanjutnya dapat dilabelkan dengan $(1,1)$ 
untuk $Y_{1}=1$ dan $Y_{2}=1,(1,0)$ untuk $Y_{1}=1$ dan $Y_{2}=0,(0,1)$ untuk $Y_{1}=0$ dan $Y_{2}=1$, dan $(0,0)$ untuk $Y_{1}=0$ dan $Y_{2}=0$.

Jika terdapat sebanyak $k$ buah variabel prediktor $X_{1}, X_{2}, \cdots, X_{k}$, maka nilai $\pi_{1}(\boldsymbol{x})$ dan $\pi_{2}(\boldsymbol{x})$ adalah model regresi logistik yang terkait dengan $Y_{1}$ dan $Y_{2}$, yang dapat dinyatakan sebagai berikut [3].

$$
\begin{aligned}
& \pi_{1}(\boldsymbol{x})=\frac{\exp \left(\beta_{01}+\beta_{11} x_{1}+\beta_{21} x_{2}+\ldots+\beta_{k 1} x_{k}\right)}{1+\exp \left(\beta_{01}+\beta_{11} x_{1}+\beta_{21} x_{2}+\ldots+\beta_{k 1} x_{k}\right)} \\
& \pi_{2}(\boldsymbol{x})=\frac{\exp \left(\beta_{02}+\beta_{12} x_{1}+\beta_{22} x_{2}+\ldots+\beta_{k 2} x_{k}\right)}{1+\exp \left(\beta_{02}+\beta_{12} x_{1}+\beta_{22} x_{2}+\ldots+\beta_{k 2} x_{k}\right)}
\end{aligned}
$$

Fungsi $\pi_{j}(\boldsymbol{x})$ merupakan suatu fungsi yang dapat digunakan untuk menentukan peluang kejadian sukses pada variabel respon $Y_{j}$ atau dapat ditulis sebagai $\pi_{j}(\boldsymbol{x})=$ $P\left(Y_{j}=1\right)$, dengan nilai probabilitas $0 \leq \pi_{j}(\boldsymbol{x}) \leq 1$. Model transformasi logit untuk $j=1,2$ adalah

$$
g_{j}(\boldsymbol{x})=\ln \left(\frac{\pi_{j}(\boldsymbol{x})}{1-\pi_{j}(\boldsymbol{x})}\right)=\beta_{0 j}+\beta_{1 j} X_{1}+\beta_{2 j} X_{2}+\cdots+\beta_{k j} X_{k}
$$

Dengan demikian model regresi logistik biner birespon dinyatakan oleh fungsi logit $g_{1}(\boldsymbol{x})$ dan $g_{2}(\boldsymbol{x})$ sebagai berikut.

$$
\begin{aligned}
& g_{1}(\boldsymbol{x})=\ln \left(\frac{\pi_{1}(\boldsymbol{x})}{1-\pi_{1}(\boldsymbol{x})}\right)=\beta_{01}+\beta_{11} X_{1}+\beta_{21} X_{2}+\ldots+\beta_{k 1} X_{k} \\
& g_{2}(\boldsymbol{x})=\ln \left(\frac{\pi_{2}(\boldsymbol{x})}{1-\pi_{2}(\boldsymbol{x})}\right)=\beta_{02}+\beta_{12} X_{1}+\beta_{22} X_{2}+\ldots+\beta_{k 2} X_{k}
\end{aligned}
$$

dengan $k$ adalah banyaknya variabel prediktor.

Lambang $\psi$ merupakan nilai odds ratio yang menunjukkan bahwa terdapat hubungan antar variabel respon, di mana nilainya adalah sebagai berikut.

$$
\psi=\frac{\pi_{11} \pi_{00}}{\pi_{10} \pi_{01}}
$$

dengan $\psi \geq 0$ jika $Y_{1}$ dan $Y_{2}$ tidak saling bebas dan $\psi=1$ jika $Y_{1}$ dan $Y_{2}$ saling bebas [1]. Selanjutnya $\ln (\psi)=\theta$ dengan $\theta=\gamma^{T} x$ dimana $\gamma$ merupakan vektor parameter terikat. $\theta$ merupakan model transformasi odds ratio dimana

$$
\begin{aligned}
& \ln \psi=\ln \left(\frac{\pi_{11} \pi_{00}}{\pi_{10} \pi_{01}}\right) \\
& \theta=\ln \psi=\ln \left(\frac{\pi_{11} \pi_{00}}{\pi_{10} \pi_{01}}\right)
\end{aligned}
$$

Model transformasi odds ratio ini dinyatakan sebagai

$$
\begin{aligned}
\theta=\ln \left(\frac{\pi_{11} \pi_{00}}{\pi_{10} \pi_{01}}\right) & =\gamma_{0}+\gamma_{1} x_{1}+\cdots+\gamma_{k} x_{k} \\
& =\gamma^{T} \boldsymbol{x}
\end{aligned}
$$

Peluang $\pi_{11}$ didefinisikan oleh $\pi_{1}, \pi_{2}$, dan $\psi$ sebagai

$$
\pi_{11}= \begin{cases}\frac{1}{2}(\psi-1)^{-1}\left(a-\sqrt{a^{2}+b}\right) & ; \psi \neq 1 \\ \pi_{1} \pi_{2} & ; \psi=1\end{cases}
$$


304 Nadya Putri Alisya dkk.

dimana $a=1+\left(\pi_{1}+\pi_{2}\right)(\psi-1)$ dan $b=-4 \psi(\psi-1) \pi_{1} \pi_{2}$. Tiga peluang lain $\pi_{10}, \pi_{01}, \pi_{00}$ diperoleh dari peluang marjinal $\pi_{1}, \pi_{2}$ dan $\pi_{11}$ sebagai berikut.

$$
\begin{aligned}
& \pi_{10}=\pi_{1}-\pi_{11} \\
& \pi_{01}=\pi_{2}-\pi_{11} \\
& \pi_{00}=1-\pi_{11}-\pi_{10}-\pi_{01}
\end{aligned}
$$

\subsection{Pendugaan Parameter Regresi Logistik Birespon}

Pendugaan parameter regresi logistik birespon dilakukan dengan menggunakan metode Maximum Likelihood Estimation (MLE). Metode ini dapat digunakan karena distribusi dari variabel acak binernya diketahui, yaitu berdistribusi binomial. Pendugaan parameter diperoleh dengan memaksimumkan fungsi likelihood. Secara umum, misalkan diberikan $Y_{1}, Y_{2}, \cdots, Y_{n}$ adalah variabel acak yang saling bebas dari populasi berdistribusi $f(\boldsymbol{y}, \boldsymbol{\theta})$, dimana $\boldsymbol{\theta}$ merupakan parameter yang akan ditaksir dan $\boldsymbol{\theta}=\left(\theta_{1}, \theta_{2}, \cdots, \theta_{k}\right)$, maka fungsi likelihood $L(\boldsymbol{\theta} \mid \boldsymbol{y})$ didefinisikan sebagai berikut [1].

$$
\begin{aligned}
L(\boldsymbol{\theta} \mid \boldsymbol{y}) & =L\left(\theta_{1}, \theta_{2}, \cdots, \theta_{k} \mid y_{1}, y_{2}, \cdots, y_{n}\right) \\
& =\prod_{i=1}^{n} p\left(y_{i} \mid \theta_{1}, \theta_{2}, \cdots, \theta_{k}\right)
\end{aligned}
$$

Penaksir MLE untuk $\boldsymbol{\theta}$ adalah nilai $\boldsymbol{\theta}$ yang memaksimumkan $L(\boldsymbol{\theta} \mid \boldsymbol{y})$ atau $\ln L(\boldsymbol{\theta} \mid \boldsymbol{y})$.

Pada data biner bivariat, dengan mengambil $n$ sampel acak yang saling bebas, maka variabel acak biner bivariat $\left(Y_{1 i}, Y_{2 i}\right)$ dimana $i=1,2, \cdots, n$ akan identik dengan variabel acak bivariat $\left(Y_{11}, Y_{10}, Y_{01}, Y_{00}\right)$ yang berdistribusi binomial dengan nilai peluang $\pi_{11}, \pi_{10}, \pi_{01}, \pi_{00}$. Fungsi likelihood dari variabel acak bivariat adalah sebagai berikut [2].

$$
\begin{aligned}
L(\boldsymbol{\beta}) & =\prod_{i=1}^{n} \pi\left(Y_{11}=y_{11 i}, Y_{10}=y_{10 i}, Y_{01}=y_{01 i}, Y_{00}=y_{00 i}\right) \\
& =\prod_{i=1}^{n} \pi_{11}^{y_{11 i}} \pi_{10}^{y_{10 i}} \pi_{01}^{y_{01 i}} \pi_{00}^{y_{00 i}}
\end{aligned}
$$

Selanjutnya

dibentuk fungsi log-natural likelihoodnya dengan me-logaritmanatural-kan fungsi likelihood di atas seperti berikut.

$$
\begin{aligned}
\ln L(\boldsymbol{\beta}) & =\ln \left(\prod_{i=1}^{n} \pi_{11}^{y_{11 i}} \pi_{10}^{y_{10 i}} \pi_{01}^{y_{01 i}} \pi_{00}^{y_{00 i}}\right) \\
& =\sum_{i=1}^{n}\left(y_{11 i} \ln \pi_{11}+y_{10 i} \ln \pi_{10}+y_{01 i} \ln \pi_{01}+y_{00 i} \ln \pi_{00}\right)
\end{aligned}
$$

Penentuan nilai taksiran parameter $\boldsymbol{\beta}$ dilakukan dengan memaksimumkan fungsi log-natural likelihoodnya, yaitu dengan menghitung turunan pertama dari fungsi log-natural likelihood kemudian disamakan nol. Turunan pertama dari fungsi log- 
natural likelihood terhadap $\boldsymbol{\beta}$ adalah

$$
\frac{\partial \ln L(\boldsymbol{\beta})}{\partial \boldsymbol{\beta}}=\sum_{i=1}^{n}\left(\frac{y_{11 i}}{\pi_{11}} \frac{\partial \pi_{11}}{\partial \boldsymbol{\beta}}+\frac{y_{10 i}}{\pi_{10}} \frac{\partial \pi_{10}}{\partial \boldsymbol{\beta}}+\frac{y_{01 i}}{\pi_{01}} \frac{\partial \pi_{01}}{\partial \boldsymbol{\beta}}+\frac{y_{00 i}}{\pi_{00}} \frac{\partial \pi_{00}}{\partial \boldsymbol{\beta}}\right)
$$

Penduga untuk $\boldsymbol{\beta}$ tidak dapat diperoleh secara langsung, karena fungsi yang dihasilkan berbentuk implisit sehingga diperlukan metode iterasi Newton Raphson. Oleh karena itu, pada penelitian ini digunakan bantuan software R-studio versi 3.4.4 dengan package vglm dan vgam untuk memperoleh nilai penaksir parameter $\boldsymbol{\beta}$.

\subsection{Kejadian Hipertensi dan Jantung Koroner}

Hipertensi dan jantung koroner merupakan penyakit yang berhubungan erat. Mereka sering terjadi bersama-sama sehingga dianggap sebagai komorbiditas (penyakit yang mungkin ada pada pasien yang sama). Berdasarkan data Kemenkes tahun 2018, angka kematian akibat komplikasi hipertensi yang terkait masalah jantung bahkan dilaporkan lebih tinggi dibandingkan jenis komplikasi yang menargetkan organ tubuh lain. Eratnya hubungan antara kedua penyakit ini juga disebabkan karena keduanya memiliki faktor risiko yang hampir sama, yaitu :

(1) Usia.

(2) Jenis Kelamin.

(3) Indeks Massa Tubuh.

(4) Kebiasaan Merokok.

(5) Aktifitas Fisik.

(6) Konsumsi Makanan Sehat.

\section{Metode Penelitian}

Data yang digunakan dalam penelitian ini adalah data Riset Kesehatan Dasar di kota Padang tahun 2013. Data pada penelitian ini didapatkan dari Kementerian Kesehatan RI dengan kerangka sampel yang ditetapkan oleh Badan Pusat Statistik.

Peubah respon dalam penelitian ini adalah kejadian hipertensi dan jantung koroner di kota Padang tahun 2013. Peubah penyerta terkait dengan kejadian hipertensi dan jantung koroner yang digunakan dalam penelitian ini adalah usia $\left(X_{1}\right)$, jenis kelamin $\left(X_{2}\right)$, indeks masa tubuh $\left(X_{3}\right)$, kebiasaan merokok $\left(X_{4}\right)$, aktifitas fisik $\left(X_{5}\right)$, konsumsi buah $\left(X_{6}\right)$ dan konsumsi sayur $\left(X_{7}\right)$.

Tahap-tahap yang dilakukan adalah :

(1) Mendeskripsikan peubah penyerta (X) dan peubah respon (Y).

(2) Menguji kebebasan antara dua peubah respon dengan statistik Pearson ChiSquare.

(3) Melakukan uji signifikansi paramater secara parsial dan serentak.

(4) Membentuk model regresi logistik birespon dan melakukan interpretasi terhadap model akhir. 
306 Nadya Putri Alisya dkk.

\section{Pembahasan}

4.1. Pengujian Signifikansi Parameter Secara Parsial

Pengujian dilakukan dengan menggunakan uji Likelihood Ratio Test dengan bantuan aplikasi R-studio 3.4.4. Hasil pengujian signifikansi parameter secara parsial dapat dilihat pada Tabel 1. 
Tabel 1. Pengujian Signifikansi Parameter Secara Parsial

\begin{tabular}{|c|c|c|c|c|c|}
\hline Variabel & Kategori & Parameter & Koefisien & Wald & P-value \\
\hline \multirow[t]{9}{*}{ Usia } & \multirow[t]{3}{*}{ Konstanta } & $\beta_{01}$ & $-5,532$ & -12.704 & $2 e-16$ \\
\hline & & $\beta_{02}$ & $-7,690$ & $-7,067$ & $1,58 e-12$ \\
\hline & & $\gamma_{0}$ & 5,814 & 2,498 & 0,012 \\
\hline & \multirow{3}{*}{$X_{1}(1)$} & $\beta_{11}$ & 1,568 & 9,045 & $2 e-16$ \\
\hline & & $\beta_{12}$ & 1,651 & 3,911 & $9,21 e-05$ \\
\hline & & $\gamma_{1}$ & $-1,172$ & $-1,287$ & 0,198 \\
\hline & \multirow[t]{3}{*}{$X_{1}(2)$} & $\beta_{21}$ & 0,592 & 3,495 & 0,0005 \\
\hline & & $\beta_{22}$ & 0,6116 & 1,453 & 0,146 \\
\hline & & $\gamma_{2}$ & $-0,643$ & $-0,712$ & 0,476 \\
\hline \multicolumn{6}{|c|}{ Likelihood Ratio Test $(G)=18,273 ; d f=3$} \\
\hline \multirow[t]{6}{*}{ Jenis Kelamin } & \multirow[t]{3}{*}{ Konstanta } & $\beta_{01}$ & $-2,473$ & $-7,817$ & $5,43 e-15$ \\
\hline & & $\beta_{02}$ & $-5,386$ & $-6,082$ & $1,19 e-09$ \\
\hline & & $\gamma_{0}$ & 3,173 & 1,671 & 0,0948 \\
\hline & \multirow[t]{3}{*}{$X_{2}$} & $\beta_{11}$ & $-0,104$ & $-0,507$ & 0,612 \\
\hline & & $\beta_{12}$ & 0,510 & 0,963 & 0,336 \\
\hline & & $\gamma_{1}$ & 0,168 & 0,148 & 0,882 \\
\hline \multicolumn{6}{|c|}{ Likelihood Ratio Test $(G)=2,31 e-13 ; d f=0$} \\
\hline \multirow[t]{9}{*}{ IMT } & \multirow[t]{3}{*}{ Konstanta } & $\beta_{01}$ & $-2,714$ & $-7,080$ & $1,44 e-12$ \\
\hline & & $\beta_{02}$ & $-4,977$ & $-5,080$ & $3,78 e-07$ \\
\hline & & $\gamma_{0}$ & 3,506 & 1,663 & 0,096 \\
\hline & \multirow[t]{3}{*}{$X_{3}(1)$} & $\beta_{11}$ & 0,044 & 0,288 & 0,773 \\
\hline & & $\beta_{12}$ & 0,194 & 0,495 & 0,620 \\
\hline & & $\gamma_{1}$ & $-0,033$ & $-0,039$ & 0,969 \\
\hline & \multirow[t]{3}{*}{$X_{3}(2)$} & $\beta_{21}$ & 0,015 & 0,100 & 0,920 \\
\hline & & $\beta_{22}$ & 0,059 & 0,150 & 0,881 \\
\hline & & $\gamma_{2}$ & $-0,026$ & $-0,031$ & 0,975 \\
\hline \multicolumn{6}{|c|}{ Likelihood Ratio Test $(G)=7,897 ; d f=3$} \\
\hline \multirow[t]{9}{*}{ Kebiasaan Merokok } & \multirow[t]{3}{*}{ Konstanta } & $\beta_{01}$ & $-2,685$ & $-9,769$ & $2 e-16$ \\
\hline & & $\beta_{02}$ & $-4,756$ & $-6,952$ & $3,6 e-12$ \\
\hline & & $\gamma_{0}$ & 5,130 & 3,402 & 0,0006 \\
\hline & \multirow[t]{3}{*}{$X_{4}(1)$} & $\beta_{11}$ & 0,119 & 0,585 & 0,558 \\
\hline & & $\beta_{12}$ & 0,247 & 0,493 & 0,622 \\
\hline & & $\gamma_{1}$ & $-1,152$ & $-1,099$ & 0,272 \\
\hline & \multirow[t]{3}{*}{$X_{4}(2)$} & $\beta_{21}$ & $-0,053$ & $-0,342$ & 0,732 \\
\hline & & $\beta_{22}$ & $-0,093$ & $-0,232$ & 0,816 \\
\hline & & $\gamma_{2}$ & $-0,211$ & $-0,238$ & 0,811 \\
\hline \multicolumn{6}{|c|}{ Likelihood Ratio Test $(G)=29,793 ; d f=3$} \\
\hline \multirow[t]{12}{*}{ Aktifitas Fisik } & \multirow[t]{3}{*}{ Konstanta } & $\beta_{01}$ & $-2,628$ & $-11,458$ & $2 e-16$ \\
\hline & & $\beta_{02}$ & $-4,557$ & $-7,939$ & $2,04 e-15$ \\
\hline & & $\gamma_{0}$ & 3,508 & 2,803 & 0,005 \\
\hline & $X_{5}(1)$ & $\beta_{11}$ & $-0,084$ & $-0,692$ & 0,489 \\
\hline & & $\beta_{12}$ & 0,391 & 1,064 & 0,287 \\
\hline & & $\gamma_{1}$ & $-0,467$ & $-0,530$ & 0,596 \\
\hline & $X_{5}(2)$ & $\beta_{21}$ & 0,292 & 0,516 & 0,606 \\
\hline & & $\beta_{22}$ & $-1,441$ & $-0,870$ & 0,384 \\
\hline & & $\gamma_{2}$ & 1,701 & 0,436 & 0,663 \\
\hline & $X_{5}(3)$ & $\beta_{21}$ & $-0,176$ & $-0,494$ & 0,621 \\
\hline & & $\beta_{22}$ & 0,865 & 0,828 & 0,408 \\
\hline & & $\gamma_{2}$ & $-1,060$ & $-0,430$ & 0,667 \\
\hline
\end{tabular}


Tabel 1. Pengujian Signifikansi Parameter Secara Parsial

\begin{tabular}{|c|c|c|c|c|c|}
\hline Variabel & Kategori & Parameter & Koefisien & Wald & $P$-value \\
\hline \multirow[t]{12}{*}{ Konsumsi Buah } & \multirow[t]{3}{*}{ Konstanta } & $\beta_{01}$ & $-2,544$ & $-10,761$ & $2 e-16$ \\
\hline & & $\beta_{02}$ & $-4,342$ & $-7,042$ & $1,9 e-12$ \\
\hline & & $\gamma_{0}$ & 3,152 & 2,282 & 0,022 \\
\hline & \multirow[t]{3}{*}{$X_{6}(1)$} & $\beta_{11}$ & $-0,133$ & $-1,366$ & 0,172 \\
\hline & & $\beta_{12}$ & $-0,402$ & $-1,467$ & 0,142 \\
\hline & & $\gamma_{1}$ & 0,614 & 0,935 & 0,350 \\
\hline & \multirow[t]{3}{*}{$X_{6}(2)$} & $\beta_{21}$ & 0,122 & 0,311 & 0,756 \\
\hline & & $\beta_{22}$ & 0,271 & 0,279 & 0,780 \\
\hline & & $\gamma_{2}$ & $-0,522$ & $-0,247$ & 0,805 \\
\hline & \multirow[t]{3}{*}{$X_{6}(3)$} & $\beta_{21}$ & $-0,044$ & $-0,176$ & 0,861 \\
\hline & & $\beta_{22}$ & $-0,065$ & $-0,102$ & 0,919 \\
\hline & & $\gamma_{2}$ & 0,151 & 0,108 & 0,914 \\
\hline \multicolumn{6}{|c|}{ Likelihood Ratio Test $(G)=6,126 ; d f=6$} \\
\hline \multirow[t]{12}{*}{ Konsumsi Sayur } & \multirow[t]{3}{*}{ Konstanta } & $\beta_{01}$ & $-2,533$ & $-10,884$ & $2 e-16$ \\
\hline & & $\beta_{02}$ & $-4,584$ & $-7,903$ & $2,71 e-15$ \\
\hline & & $\gamma_{0}$ & 3,445 & 2,746 & 0,006 \\
\hline & \multirow[t]{3}{*}{$X_{7}(1)$} & $\beta_{11}$ & $-0,280$ & $-2,926$ & 0,003 \\
\hline & & $\beta_{12}$ & 0,055 & 0,226 & 0,821 \\
\hline & & $\gamma_{1}$ & 0,141 & 0,265 & 0,790 \\
\hline & \multirow[t]{3}{*}{$X_{7}(2)$} & $\beta_{21}$ & 0,499 & 1,221 & 0,222 \\
\hline & & $\beta_{22}$ & $-0,161$ & $-0,145$ & 0,885 \\
\hline & & $\gamma_{2}$ & $-0,283$ & $-0,116$ & 0,908 \\
\hline & \multirow[t]{3}{*}{$X_{7}(3)$} & $\beta_{21}$ & $-0,257$ & $-0,986$ & 0,324 \\
\hline & & $\beta_{22}$ & 0,087 & 0,125 & 0,900 \\
\hline & & $\gamma_{2}$ & 0,131 & 0,085 & 0,932 \\
\hline
\end{tabular}

Berdasarkan Tabel 1 dengan menggunakan Likelihood Ratio Test dan statistik uji $G$ dapat dilihat bahwa variabel jenis kelamin, imt, konsumsi buah dan konsumsi sayur tidak berpengaruh terhadap model karena nilai statistik uji $G$ yang dihasilkan kecil dari nilai $\chi_{(0,05 ; d f)}^{2}$ dengan derajat bebas masing-masing.

Variabel usia berpengaruh terhadap model karena memiliki nilai statistik uji $G$ sebesar 18,273 yang lebih besar dari $\chi^{2}$ tabel pada taraf nyata 0,05 dan derajat bebas 3 yaitu 7,815. Variabel kebiasaan merokok juga berpengaruh terhadap model karena memiliki nilai statistik uji $G$ sebesar 29,793 yang lebih besar dari $\chi^{2}$ tabel pada taraf nyata 0,05 dan derajat bebas 3 yaitu 7,815. Begitu juga dengan variabel aktifitas fisik yang berpengaruh terhadap model karena nilai statistik uji $G$ yang dihasilkan yaitu 127,509 lebih besar dari nilai $\chi^{2}$ tabel pada taraf nyata 0,05 dan derajat bebas 6 yaitu 12,592.

Pada uji Wald, variabel prediktor dikatakan signifikan atau berpengaruh terhadap variabel respon jika nilai statistik uji Wald yang dihasilkan lebih besar dari $\chi_{(0,05 ; 1)}^{2}=3,814$ atau nilai p-value lebih kecil dari 0,05. Berdasarkan hasil yang diperoleh pada tabel 1 hanya variabel usia yang memenuhi syarat statistik uji Wald sehingga dapat disimpulkan bahwa dari ketujuh variabel hanya variabel usia $\left(X_{1}\right)$ yang berpengaruh terhadap kejadian hipertensi dan jantung koroner. Hasil dari pengujian secara parsial ini kemudian diambil untuk selanjutnya dilakukan pengujian signifikansi parameter secara serentak. 


\subsection{Pengujian Signifikansi Parameter Secara Serentak}

Setelah dilakukan pengujian signifikansi parameter secara parsial, diperoleh bahwa hanya faktor risiko usia yang berpengaruh terhadap model. Selanjutnya dilakukan pengujian signifikansi parameter secara serentak untuk memperoleh model akhir regresi logistik birespon. Pengujian ini juga menggunakan uji Likelihood Ratio Test dengan bantuan aplikasi R-studio 3.4.4. Hasil pengujian signifikansi parameter secara parsial dapat dilihat pada Tabel 2 .

Tabel 2. Pengujian Signifikansi Parameter Secara Serentak

\begin{tabular}{|c|c|c|c|c|c|}
\hline Variabel & Kategori & Parameter & Koefisien & Wald & P-value \\
\hline \multirow[t]{9}{*}{ Usia } & \multirow[t]{3}{*}{ Konstanta } & $\beta_{01}$ & $-5,532$ & -12.704 & $2 e-16$ \\
\hline & & $\beta_{02}$ & $-7,690$ & $-7,067$ & $1,58 e-12$ \\
\hline & & $\gamma_{0}$ & 5,814 & 2,498 & 0,012 \\
\hline & \multirow[t]{3}{*}{$X_{1}(1)$} & $\beta_{11}$ & 1,568 & 9,045 & $2 e-16$ \\
\hline & & $\beta_{12}$ & 1,651 & 3,911 & $9,21 e-05$ \\
\hline & & $\gamma_{1}$ & $-1,172$ & $-1,287$ & 0,198 \\
\hline & \multirow[t]{3}{*}{$X_{1}(2)$} & $\beta_{21}$ & 0,592 & 3,495 & 0,0005 \\
\hline & & $\beta_{22}$ & 0,6116 & 1,453 & 0,146 \\
\hline & & $\gamma_{2}$ & $-0,643$ & $-0,712$ & 0,476 \\
\hline \multicolumn{6}{|c|}{ Likelihood Ratio Test $(G)=18,273 ; d f=3$} \\
\hline
\end{tabular}

Pada pengujian signifikansi secara serentak diperoleh bahwa nilai statistik uji $G$ sebesar 18,273 lebih besar dari nilai $\chi^{2}$ tabel pada taraf nyata 0,05 dan derajat bebas 3 yaitu 7,815. Selanjutnya variabel usia dapat dimasukkan ke dalam model akhir.

Model akhir yang terbentuk adalah sebagai berikut.

Model logit 1 :

$$
\begin{aligned}
\ln \left(\frac{\pi_{1}(x)}{1-\pi_{1}(x)}\right)= & \beta_{01}+\beta_{11} X_{1}(1)+\beta_{21} X_{1}(2) \\
& =-5,532+1,568 X_{1}(1)+0,592 X_{1}(2)
\end{aligned}
$$

Model $\operatorname{logit} 2$ :

$$
\begin{aligned}
\ln \left(\frac{\pi_{2}(x)}{1-\pi_{2}(x)}\right)= & \beta_{02}+\beta_{12} X_{1}(1)+\beta_{22} X_{1}(2) \\
& =-7,690+1,651 X_{1}(1)+0,6116 X_{1}(2)
\end{aligned}
$$

Model transformasi odds ratio :

$$
\begin{aligned}
\ln \left(\frac{\pi_{11} \pi_{00}}{\pi_{10} \pi_{01}}\right)= & \gamma_{0}+\gamma_{1} X_{1}(1)+\gamma_{2} X_{1}(2) \\
& =5,814-1,172 X_{1}(1)-0,643 X_{1}(2)
\end{aligned}
$$

Bila dinyatakan dalam model peluang marjinal maka diperoleh model sebagai berikut.

Model peluang marjinal $Y_{1}$ :

$$
\pi_{1}(x)=\frac{\exp \left(\beta_{01}+\beta_{11} X_{1}(1)+\beta_{21} X_{1}(2)\right.}{1+\exp \left(\beta_{01}+\beta_{11} X_{1}(1)+\beta_{21} X_{1}(2)\right)}
$$




$$
=\frac{\exp \left(-5,532+1,568 X_{1}(1)+0,592 X_{1}(2)\right.}{1+\exp \left(-5,532+1,568 X_{1}(1)+0,592 X_{1}(2)\right)}
$$

Model peluang marjinal $Y_{2}$ :

$$
\begin{aligned}
\pi_{2}(x)= & \frac{\exp \left(\beta_{02}+\beta_{12} X_{1}(1)+\beta_{22} X_{1}(2)\right.}{1+\exp \left(\beta_{02}+\beta_{12} X_{1}(1)+\beta_{22} X_{1}(2)\right)} \\
& =\frac{\exp \left(-7,690+1,651 X_{1}(1)+0,6116 X_{1}(2)\right.}{1+\exp \left(-7,690+1,651 X_{1}(1)+0,6116 X_{1}(2)\right)}
\end{aligned}
$$

\subsection{Interpretasi Model Regresi Logistik Birespon}

Interpretasi model akhir dilakukan dengan menggunakan nilai odds ratio pada masing-masing persamaan. Nilai odds ratio dari masing-masing persamaan yang diperoleh adalah sebagai berikut.

Tabel 3. Nilai Odds Ratio

\begin{tabular}{|r|c|c|c|c|}
\hline Variabel & Kategori & Parameter & Koefisien & Odds Ratio \\
\hline Usia & Konstanta & $\beta_{01}$ & $-5,532$ & 0.0039 \\
& & $\beta_{02}$ & $-7,690$ & 0.0004 \\
& & $\gamma_{0}$ & 5,814 & 334.9563 \\
\hline & $X_{1}(1)$ & $\beta_{11}$ & 1,568 & 4.7970 \\
& & $\beta_{12}$ & 1,651 & 5.2121 \\
& & $\gamma_{1}$ & $-1,172$ & 0.3097 \\
\hline \multirow{3}{*}{$X_{1}(2)$} & $\beta_{21}$ & 0,592 & 1.8076 \\
& & $\beta_{22}$ & 0,6116 & 1.8434 \\
& & $\gamma_{2}$ & $-0,643$ & 0.5257 \\
\hline
\end{tabular}

Berdasarkan model akhir yang diperoleh, diketahui bahwa faktor risiko usia yang berpengaruh terhadap kejadian hipertensi dan jantung koroner dengan kategori $(0,0)$ apabila tidak terjadi hipertensi dan tidak terjadi jantung koroner, $(0,1)$ apabila tidak terjadi hipertensi tetapi terjadi jantung koroner, $(1,0)$ apabila terjadi hipertensi tetapi tidak terjadi jantung koroner, dan $(1,1)$ apabila terjadi hipertensi dan jantung koroner.

Bentuk persamaan probabilitas regresi logistik birespon pada kategori $(0,1)$, jika $Y_{1}=0, Y_{2}=1$ sebagai berikut.

$$
P\left(Y_{1}=0, Y_{2}=1\right)=\frac{\exp \left(-7,690+1,651 X_{1}(1)+0,6116 X_{1}(2)\right.}{1+\exp \left(-7,690+1,651 X_{1}(1)+0,6116 X_{1}(2)\right)} .
$$

Interpretasi dari model regresi logistik birespon jika $Y_{1}=0, Y_{2}=1$ adalah jika faktor risiko usia berpengaruh terhadap kejadian tidak terjadi hipertensi dan terjadi jantung koroner maka berdasarkan nilai odds ratio disimpulkan bahwa jika responden berusia antara 45 sampai 64 tahun, maka risiko responden tersebut tidak mengalami hipertensi dan mengalami jantung koroner adalah sebesar 5,2121 kali dibandingkan responden yang berusia kurang dari 45 tahun. Jika responden berusia lebih dari 64 tahun, maka risiko responden tersebut tidak mengalami hipertensi dan mengalami jantung koroner adalah sebesar 1,8434 kali dibandingkan responden yang berusia kurang dari 45 tahun. 
Bentuk persamaan probabilitas regresi logistik birespon pada kategori $(1,0)$, jika $Y_{1}=1, Y_{2}=0$ sebagai berikut.

$$
P\left(Y_{1}=1, Y_{2}=0\right)=\frac{\exp \left(-5,532+1,568 X_{1}(1)+0,592 X_{1}(2)\right.}{1+\exp \left(-5,532+1,568 X_{1}(1)+0,592 X_{1}(2)\right)} .
$$

Interpretasi dari model regresi logistik birespon jika $Y_{1}=1, Y_{2}=0$ adalah jika faktor risiko usia berpengaruh terhadap kejadian terjadi hipertensi dan tidak terjadi jantung koroner, berdasarkan nilai odds ratio disimpulkan bahwa jika responden berusia antara 45 sampai 64 tahun, maka risiko responden tersebut mengalami hipertensi dan tidak mengalami jantung koroner adalah sebesar 4,7970 kali dibandingkan responden yang berusia kurang dari 45 tahun. Jika responden berusia lebih dari 64 tahun, maka risiko responden tersebut mengalami hipertensi dan tidak mengalami jantung koroner adalah sebesar 1,8076 kali dibandingkan responden yang berusia kurang dari 45 tahun.

Bentuk persamaan probabilitas regresi logistik birespon pada kategori $(1,1)$, jika $Y_{1}=1, Y_{2}=1$ sebagai berikut.

$$
P\left(Y_{1}=1, Y_{2}=1\right)=\frac{\exp \left(5,814-1,172 X_{1}(1)-0,643 X_{1}(2)\right.}{1+\exp \left(5,814-1,172 X_{1}(1)-0,643 X_{1}(2)\right)} .
$$

Interpretasi dari model regresi logistik birespon jika $Y_{1}=1, Y_{2}=1$ adalah jika faktor risiko usia berpengaruh terhadap kejadian terjadi hipertensi dan jantung koroner, berdasarkan nilai odds ratio disimpulkan bahwa jika responden berusia antara 45 sampai 64 tahun, maka risiko responden tersebut mengalami hipertensi dan jantung koroner adalah sebesar 0,3097 kali dibandingkan responden yang berusia kurang dari 45 tahun. Jika responden berusia lebih dari 64 tahun, maka risiko responden tersebut mengalami hipertensi dan jantung koroner adalah sebesar 0,5257 kali dibandingkan responden yang berusia kurang dari 45 tahun.

\section{Kesimpulan}

Berdasarkan hasil penelitian diambil kesimpulan sebagai berikut

(1) Dari tujuh faktor risiko yang diduga mempengaruhi kejadian hipertensi dan jantung koroner di kota Padang berdasarkan data riset kesehatan dasar 2013, diperoleh bahwa dengan menggunakan analisis regresi logistik birespon hanya faktor risiko usia $\left(X_{1}\right)$ yang berpengaruh signifikan terhadap variabel respon.

(2) Responden yang paling berisiko tidak mengalami hipertensi dan mengalami jantung koroner adalah responden yang berusia 45-64 tahun dengan nilai odds ratio sebesar 5,2121. Responden yang paling berisiko mengalami hipertensi dan tidak mengalami jantung koroner adalah responden yang berusia 45-64 tahun dengan nilai odds ratio sebesar 4,7970. Responden yang paling berisiko mengalami hipertensi dan jantung koroner adalah responden yang berusia lebih dari 64 tahun dengan nilai odds ratio sebesar 0,5257.

\section{Ucapan Terima kasih}

Penulis mengucapkan terimakasih kepada Ibu Lyra Yulianti, Ibu Izzati Rahmi HG dan Bapak Admi Nazra yang telah memberikan masukan dan saran sehingga paper 
312 Nadya Putri Alisya dkk.

ini dapat diselesaikan dengan baik.

\section{Daftar Pustaka}

[1] Casella, G. dan RL. Berger. 2002. Statistical Inference Second Edition. Pacific Grove : Duxbury Press

[2] Cessie, L. dan Houwelingen, J.C. 1994. Logistic Regression for Correlated Binary Data. Applied Statistic. Volume 42. Hal : 95-108

[3] Hosmer, D.W. dan Lemeshow, S. 2000. Applied Logistic Regression. New York : John Wiley and Sons

[4] Nirwana, S.R.A. 2015. Regresi Logistik Multinomial dan Penerapannya dalam Menentukan Faktor yang Berpengaruh pada Pemilihan Program Studi di Jurusan Matematika UNM. Skripsi. Makassar : Universitas Negeri Makassar

[5] Paliati, H. 2003. Beberapa Faktor Risiko Penyakit Jantung Koroner pada Pasien Rawat Inap di RSUP Dr. Wahidin Sudirohusodo Makassar. Skripsi. Program sarjana. Makassar : Universitas Hasanuddin

[6] Rahajeng dan Tuminah. 2009. Prevalensi Hipertensi dan Determinannya di Indonesia. Pusat Penelitian Biomedis dan Farmasi. Jakarta : Badan Penelitian Kesehatan Departemen Kesehatan RI 